Journal of Social Sciences 7 (1): 24-32, 2011

ISSN 1549-3652

(C) 2010 Science Publications

\title{
Who Really Cares About Higher Education For Sustainable Development?
}

\author{
${ }^{1}$ Torsten Richter and ${ }^{2}$ Kim Philip Schumacher \\ ${ }^{1}$ Department of Biology, University of Hildesheim, Marienburger Platz 22, \\ 31141 Hildesheim, Germany \\ ${ }^{2}$ Institute for Spatial Analysis and Planning in Areas of Intensive Agriculture (ISPA), \\ University of Vechta, Driverstrasse 22, 49377 Vechta, Germany
}

\begin{abstract}
Problem statement: It is agreed that integrating Higher Education for Sustainable Development (HESD) into the curricula of universities is of key importance to disseminate the idea of sustainability. Especially the curricula of teacher-training should contain elements of Education for Sustainable Development (ESD) due to the crucial role of future teachers in information propagation. Approach: In order to find out about the spreading of ESD into the curricula and whether or not it is of interest to university staff and students two interlinked studies were carried out in northern Germany during the summer term 2009 using standardized questionnaires. Results: A large gap between pilot projects and the statements of politicians on the one hand and the interest of academic staff and students in sustainability issues and the dissemination of HESD and ESD into the standard curricula of universities on the other was observed. Only $20 \%$ of respondents stated to have either given or attended courses relating to sustainability. Conclusion/Recommendations: Nevertheless there is a strong approval of the necessity for more courses related to sustainability which offers potential for improvements within the rest of the UN-Decade on Education for Sustainable Development (ESD).
\end{abstract}

Key words: Higher education, sustainability, teacher training, Education for Sustainable Development (ESD), UN Decade of ESD

\section{INTRODUCTION}

It is commonly agreed that integrating Higher Education for Sustainable Development (HESD) into the curricula of universities is of key importance to disseminate the idea of sustainability (Corcoran and Wals, 2004a). Especially the curricula of teachertraining should contain elements of Education for Sustainable Development (ESD) due to the crucial role of future teachers in information propagation (Schneidewind, 2009). This seems the single most important factor in order to reach a turn-around for a sustainable future.

Five years into the UN-Decade of ESD carried out by UNESCO there exist a lot of ground breaking projects and well documented examples of good practice scattered all over the world (Adomssent et al., 2006).

Germany in particular regards itself as a country that is well above average on a global scale regarding environmental issues and the implementation of ESD into its curricula (de Haan and Leicht, 2009). As a consequence of the Agenda 21, resolved at the UN
Conference on Environment and Development in Rio de Janeiro in 1992, Germany started comparatively early its own programme for the implementation of ESD into the educational system, called the BLK 21 programme. This programme ran from 1999-2004 and prepared a general shift from input or knowledge oriented learning to output orientation where the educational aim is focused on the pupils competencies, namely the so-called 'shaping competence' (De Haan, 2006). The German Federal Parliament again recognized the important role of ESD for a sustainable future in 2004 by greeting the start of the UN-Decade for ESD in unison (Deutscher Bundestag, 2004). The new German Government recently confirmed this in its coalition agreement in October 2009.

Within Germany's federal structure, ESD is already implemented in legal documents on the level of the German state, the federal states and also in various regional and local school programmes. Over 1000 projects have been registered as an "Official German Decade Project" in the UN-Decade for ESD so far by the German Commission for UNESCO (www.bneportal.de). Germany is currently in the process of

Corresponding Author: Department of Biology, University of Hildesheim, Marienburger Platz 22, 31141 Hildesheim, Germany Tel: +49-5121-883-931 
defining binding nationwide standards for school curricula ('Bildungsstandards') for the major school subjects such as biology, German language, or mathematics (BMBF, 2007). These have to be implemented by the German federal states into their legal framework. Note that education (both school and university) is within the sovereignty of the federal states in Germany which produces differences amongst the states.

Since the idea of sustainability and sustainable living is, for example, explicitly mentioned in the school subject biology for all kinds of schools, all federal states have to implement ESD in biology within their frameworks. Furthermore, taking the federal state of Lower Saxony as an example, ESD has to be taught in a various array of school subjects as diverse as social studies and science in primary schools as well as politics, geography, chemistry, physics, biology, social sciences, ethics and economy in the various kinds of secondary schools. The importance of ESD for school curricula is still on the rise according to the government official in charge of curricula development at the responsible ministry (Henke, R. Lower Saxony Ministry of Education, pers. com. November 2009).

Despite of this body of evidence and more than 30 years of efforts to implement HESD (Wright, 2004), we argue that even halfway into the UN-Decade for ESD there is still a gap between the polished pilot projects and the statements of politicians on the one hand and the interest of academic staff and students in sustainability issues and the dissemination of HESD and ESD into the standard curricula of universities on the other. This is emphasized by recent studies in Malaysia, Great Britain and Australia that reveal a deficit in students' knowledge about sustainability (Idros and Mohamed, 2009; Kagawa, 2007; Stir, 2006).

Therefore a quantitative study was conducted in northern Germany in order to gain insight into the actual relevance of teaching ESD in university courses, especially in teacher training and the general knowledge and attitudes of academic university staff towards (Higher) Education for Sustainable Development at eight universities in Lower Saxony.

\section{MATERIALS AND METHODS}

In order to find out about the spreading of ESD into the curricula and whether or not it is of interest to university staff and students we carried out two interlinked studies at the University of Hildesheim and as online survey at the eight other Universities in Lower Saxony and the University of Bremen during the summer term 2009. The University of Hildesheim is located in the federal state of Lower Saxony in northern Germany and has 5,000 students, a teaching staff of around 360 and ca. 200 administrative employees. Approximately one third of the students are teacher trainees, teaching being traditionally a special degree programme in Germany. The study's focus lies with the teacher trainees and scientific staff since the former will be the major promoters of ESD in coming years whilst the latter define the curricula for the students. Officially, HESD plays no major role at University of Hildesheim so far.

A printed questionnaire was presented to students on campus or alternatively to all students and staff as an online version. It contained questions measuring attitudes towards sustainability on a four-scaled Likert scale. The questionnaire covered the fields of knowledge of the concept of sustainability, attitudes towards sustainable behaviour, willingness to pay for more sustainable products and services and attendance of and potential interest in university courses concerning the subject of sustainability.

In total about 1,000 students and members of staff answered our study-and online-questionnaires, adding up to a set of 751 completed forms of which 668 were answered by students, 46 by teaching and 37 administrative employees.

This gives a percentage of participation of roughly $13,4 \%$ of the student body, $12,8 \%$ of teaching and $18,5 \%$ of administrative employees. Of the participating students roughly one third were teacher trainees. This resembles their actual quota of students at Hildesheim University.

The second questionnaire was directed only at academic teaching staff and contained questions measuring attitudes towards the importance of HESD and the degree programmes that should relate to sustainability on a 5-point Likert scale. In detail, we asked for knowledge of the concept of sustainability, the knowledge of the UN Decade for ESD, concepts associated with the term sustainability, own university courses taught relating to sustainability so far, interest in a shared university calendar listing courses relating to sustainability at all northern universities and if sustainability should become a new key qualification.

The questionnaire was distributed on study to the approx. 360 scientific members of the University of Hildesheim. To increase the robustness of the study, members of academic staff at eight other universities in Lower Saxony and the University of Hildesheim were interviewed as well using an identical onlinequestionnaire.

1244 persons participated in the online questioning (study-form 72), 701 of these completing the 
questionnaire (study-form 70), giving overall 771 completed forms. Therefore in Hildesheim $20 \%$ of the teaching staff participated in the survey. The response rate of staff interviewed online is much more difficult to calculate. In 2006, according to state-wide statistics (Niedersaechsisches Landesamt für Statistik, 2008), the questioned universities in Lower Saxony employed 9,600 scientists and the University of Bremen 1,500. By subtracting $10 \%$ as sole research staff, we get a number of approx. 10.000 members of teaching staff. This results in a participation rate of roughly $13.2 \%$ for the general population with approximately $7.7 \%$ completing the questionnaire. All data analysis was carried out with the statistical package SPSS 17.0.

\section{RESULTS}

First of all it is interesting to note that those respondents from the teaching staff, who did not answer the questionnaire completely, already stopped at the page of introduction or the first two questions ( $n$ $=393,31.6 \%$ of the 1244 participants accessing it online). The page of introduction and the first two questions dealt with the concept of sustainability in general terms. When comparing the two groups that either completed the questionnaire or broke of, it is apparent that those who broke of were significantly more often unsure at the start if they had knowledge of the concept of sustainability in general $(16 \%$ answering "not sure" opposed to $12 \%$ that completed the form; $\mathrm{p}=0,024$, chi-square test, $\mathrm{n}=898)$. Significant differences were even more apparent in personal knowledge of the ongoing UN-Decade for ESD. The right answer (we are currently in the UNDecade of ESD) here was only given by $5 \%$ of those who broke of in contrast to $18 \%$ who continued, $85 \%$ respectively $73 \%$ answering they did not know the answer $(\mathrm{p}=0,003$, chi-square test, $\mathrm{n}=840)$. We conclude therefore that disproportionately often those scientists broke of filling out the questionnaire that did not know the concept of sustainability, were not interested in or even opposed to it.

A similar trend was apparent in the answering pattern of the students in the first survey. In general, those who answered the online questionnaire were more open minded towards sustainability than those filling out the questionnaire, handed out to them by their fellow students. We conclude that those students who received the questionnaire from a peer felt a stronger obligation to fill it out even if they were not interested in sustainability, whereas those completing the online version had an overall greater general interest in the subject and were participating voluntarily.
We suppose that we thereby gathered data of a subset of the population under study that is somewhat in favour of sustainability. We conclude that our data are therefore biased to draw a picture which is more favourable towards sustainability than is realistic when regarding the population under study as a whole.

The general concept of sustainability was common to $61 \%$ of teaching staff, unknown to $26 \%$ and $13 \%$ being undecided $(n=898)$. When asked if we are currently in the UN-Decade for ESD while offering some invented alternatives, only $16 \%$ of teaching staff knew the correct answer, $10 \%$ choose one of the nonexistent alternatives and $74 \%$ answered they did not know $(\mathrm{n}=840)$. The correct knowledge showed differences between universities: the smaller ones and those with an ongoing tradition of implementing HESD in the lead.

In order to find out about the understanding of the concept of sustainability, eight alternatives were given plus the possibility to write an individual answer. The teaching staff chose answers significantly different ( $\mathrm{p}<0,001$, chi-square test, $\mathrm{n}=887$ ). Most answers were chosen more or less by half of the participants. The least chosen one was "balancing of interests" (16\%), most frequently chosen was "preservation of resources" (71\%) followed by "balancing economy and ecology" $(53 \%)$. Within the answers of the students, there was a similar trend to over express the role of ecology and (technical) protection of the environment and resources and a general underrepresentation of social, cultural and/or ethical dimensions of sustainability.

So far, only $18 \%$ of teaching staff stated to have at least once given a course relating to sustainability, $80 \%$ had never given such a course and $2 \%$ did not know $(n=757)$. This is more or less in accordance with the students, of which $32 \%$ said they had attended at least one course relating to sustainability so far, $60 \%$ had not and $8 \%$ were not sure $(n=604)$. Note that the questions were posed in a weak form, not asking for courses explicitly targeting sustainability but just relating to it in some form.

In a projection to all courses taught (teaching load is approx. eight courses per year) within one year at Germanys northern universities, it can be assumed that at present more than $95 \%$ of university courses do not even relate to sustainability in any way. Keeping in mind that our data are most likely biased in favour of sustainability, the real number should even be lower.

Given the strong approval for HESD to be implemented at least in the degree programmes of teacher training (see below), this obviously does not relate to actual teaching so far. Answers of academic staff being within teacher training degrees programmes 
and ones without did not differ. From the former group $20 \%$ had given courses relating to sustainability, from the latter $19 \%(n=671), 79 \%$ of both groups had not raised this subject in teaching.

Contrary to the current teaching situation, approval to broaden teaching activities in the future is very strong. $55 \%$ of teaching staff agree upon sustainability being implemented in all degree programmes at university, with $23 \%$ being undecided and $22 \%$ opposing $(\mathrm{n}=663)$. Approval rises to $76 \%$ that sustainability should be a mandatory subject in teacher training programmes $(17 \%$ undecided and $7 \%$ opposing, $n=623$ ). A majority of $64 \%$ of respondents do not see a threat to their freedom of research and teaching if teaching sustainability should be implemented generally. Only $20 \%$ see a threat and the rest is undecided $(n=610)$. A threat was mainly seen within the group teaching for 3 up to 10 years (26\%). This is the group actually trying to become permanently established within the scientific community.

Of all respondents $61 \%$ oppose the statement that sustainability has no connection to ones profession within degree programmes, with $14 \%$ being indecisive and $25 \%$ in agreement $(n=639)$.

There was also broad approval that the number of courses relating to sustainability should be increased $(56 \%, \mathrm{n}=561)$, respectively those of a truly interdisciplinary kind $(65 \%, \mathrm{n}=583)$. Only $16 \%$ were of the opinion that there are sufficient courses already $(n=411)$. Here the uncertainty within participants was unusually high, with up to 300 choosing to opt for "no answer".

Data are ambiguous when asked if sustainability should become a new key qualification. $41 \%$ opted for sustainability as a new field of key qualifications, 37\% objected and $22 \%$ were unsure $(n=584)$. The Bologna process of reforming the university curricula throughout Europe makes it mandatory that so-called key qualifications have to be part of every single degree programme. They complement training outside the strict subjects of degree courses.

The students at the University of Hildesheim expressed a clear preference to attend courses relating to sustainability if offered any $(51 \%)$, with $33 \%$ being indecisive so far and only $16 \%$ would not attend such courses $(n=604)$. Interestingly, lack of interest here was highest within the faculty of natural sciences and with teacher trainees.

Overall, $84 \%$ of students agreed that the university should act growingly sustainable as a whole in the near future. But only a minority is willing to play an active role here, expecting the university to react at an institutional level instead. $67 \%$ of students never participate in any kind of voluntary activities at the university, mostly claiming lack of time within the tight schedule of the new bachelor and master programmes.

\section{DISCUSSION}

Starting point for the research reported in this paper was the question in how far ESD is implemented into the university curricula in North-German universities. Additionally we examined the knowledge of the aims of the current UN-Decade of ESDE with university staff and students. As the results show the presumed gap between the requirements for ESD in school-curricula on the level of the federal states and the university courses on ESD for (especially) teachertrainees offered so far really exists. Furthermore, the general knowledge of university staff and students on HESD and the UN-Decade is limited and, in addition mostly superficial. On a national level there exists no similar study in Germany so far that examines the role of sustainable development or HESD on the level of awareness of academic staff or its overall implementation into university curricula.

In Germany, the environmental awareness of the overall population is monitored every two years by the Federal Ministry for the Environment (BMU). Environmental protection is highly valued with $91 \%$ of the citizens agreeing that it is an important societal task (BMU, 2008; $\mathrm{n}=2021$ ). But the concept of sustainability is far less commonly known. During the 2004 survey, only $22 \%$ of the population had at least heard of sustainable development (SD) and only $11 \%$ had a more than superficial knowledge of the concept of SD (BMU, 2004; n = 2018). Overall, agreement to environmental and/or sustainability topics is overwhelming, but generally the state is seen as the foremost agent, with only a smaller percentage of the respondents willing to act in a more sustainable fashion personally.

The Brandenburg University of Technology (BTU) in Cottbus conducted a survey in 2009 on the environmental awareness of its scientific and administrative staff and students as one step on its way to get certified by EMAS, the European EcoManagement and Audit Scheme $(n=2155,28,1 \%$ of the population under study) (Schluchter and Kunze, 2010). They found the general environmental awareness at the BTU Cottbus is higher than in the aforementioned studies by the BMU. Nevertheless even in the middle of the process of implementing EMAS at their university; only one out of four could describe the meaning and aims of EMAS. There was also a noticeable drop in the reported personal commitment: 
almost everyone wished that the university acted more sustainable on an institutional level, but less than half of those participating in the study had already bought a product because it was environmentally friendly.

In spring of 2007 Riess and Mischo (2007) conducted a survey on 81 secondary schools in the Federal State of Baden-Wuerttemberg in order to assess the significance of sustainability for school teaching. They found that $71 \%$ of teachers $(n=1835)$ at least knew the term "sustainable development", but only $29 \%$ had heard of "education for sustainable development". More than two years into the UNDecade for ESD already, only 2,2\% of teachers knew the UN-Decade good enough to name some of its aims spontaneously, another 5,8 \% could name some aims after some thinking and the majority of $72 \%$ never had heard of the UN-Decade at all. Even worse were the results for nationwide action programmes especially designed to disseminate the idea of ESD into schools in the aftermath of the Earth Summit in Rio 1992 (the "BLK 21" and "Transfer 21") This programmes were not known to $83 \%$ of teachers, $12 \%$ had heard of them without knowing their aims and only $1,4 \%$ could refer to the programmes and their aims spontaneously (Riess and Mischo, 2007).

The results of our survey indicate a slightly better awareness and knowledge of ESD among university staff, which might also be a result of more publicity in scientific discourse and the media with the advancement of the UN-Decade. Nevertheless the aforementioned studies and our own research reveal a general trend of high environmental awareness, but no profound knowledge of ESD and a very slow integration into school and university teaching on a general level in Germany.

Another problem with HESD is that despite the consent of its importance in teaching at university today, only a minority of teaching staff $(18 \%)$ in the presented study have given a course related to sustainability at least once so far. It has already been pointed out that we only asked for a weak relation of courses to sustainability, not even for courses with sustainability as their main theme. Quite dispiritingly, the situation was the same for teacher training programmes.

Similar problems were found recently by Desha et al. (2009) when researching current engineering education for sustainable development. They termed it the time lag dilemma in curriculum renewal, referring to the gap between societal demands on competencies of university graduates on the one hand and actual university curricula on the other (Desha et al., 2009).
On an international level more insight into the actual dissemination of ESD into university curricula has been gained but studies are often limited to a single university or course with mostly few participants.

An exception are surveys in the field of engineering education in order to assess the extent of engineering education for sustainable development (see review in: Desha and Hargroves, 2010). From the surveys reviewed and their own work they conclude their findings "suggest a lack of sustainability knowledge and skills in engineering curriculum" (Desha and Hargroves, 2010). On the other hand in a survey for the Centre of Sustainable Engineering (CSE) during 2007 in the USA the authors found that $23 \%$ of the responding engineering departments reported B.Sc. or M.Sc. programmes that related to sustainability and an astonishing $80 \%$ reported sustainability content in at least some courses taught by them (Davidson et al., 2010). But while only one fifth of the engineering departments addressed during this study actually responded to the questionnaire, the data may well be biased to draw a more favourable picture for HESD as in our survey, since engineering departments indifferent or opposed to sustainability may well not have participated.

In general, curriculum renewal at least in engineering education is seen as a very challenging and time-consuming task, leading in consequence to an overemphasis on older content in courses and obstructing the integration of sustainable engineering in current curricula (Davidson et al., 2010).

Attempts to shift the teacher education program towards ESD are also made at the Universiti Sains Malaysia in Penang (Idros and Mohamed, 2009). In this process a review of the current state of awareness of SD and the willingness to teach ESD was conducted within undergraduate students $(n=615)$ pre-service teacher students $(n=473)$ and university staff $(n=32)$. In this study $69,5 \%$ of undergraduate students stated to have only little or no knowledge at all about ESD (for the UK see also Kagawa, 2007). 94,5\% of the pre-service teachers stated that their willingness in teaching for sustainability is very high. The quota among the staff is even higher than that of the students but only $5 \%$ stated that they knew a lot about ESD (Idros und Mohamed, 2009).

Summing up the existing studies reveals a broad positive attitude towards sustainable development and the necessity to teach ESD in school and at universities. It was necessary to highlight the situation at German universities in order to estimate the possibilities and further needs to incorporate ESD into the curriculum. 


\section{CONCLUSION}

It is well known that the mainstreaming of HESD has encountered numerous problems so far (Corcoran and Wals, 2004b; Holmberg and Samuelsson, 2006). Towards the mid-term of the UN-Decade for ESD there were already concerns that ESD appealed mostly to those already 'converted', being of minor importance to most governments that lacked deeper engagement to implement the necessary changes (Mula and Tilbury, 2009). Right now we are already more than halfway through the entire UN-Decade for ESD that started in 2005 with great enthusiasm. Despite the well-known, well publicised and sufficiently financed pilot-projects, HESD appears to not having arrived in Germany's academic mainstream so far, as the results of this study illustrate. The crucial question is: Will it ever?

Starting with the fact that despite a superficial general knowledge of the term sustainability (coined already 30 years ago), the UN-Decade itself is not known to even one sixth of teaching staff at NorthGerman universities. Keep in mind that we have good cause to believe our data to be in favour of the case for sustainability already. Furthermore there seems to be a severe communication problem so far that was also stated at the closing session of the UNESCO World Conference on Education for Sustainable DevelopmentMoving into the Second Half of the UN Decade in Bonn on April, 22009 by De Haan (2006), the chairman of Germanys national committee on ESD (UNESCO, 2009).

Our survey shows that not even one third of today's students have even encountered the concept of sustainability in any course during Higher Education. Despite the general agreement that at least teacher trainees should understand sustainability issues in order to be able to successfully teach ESD later on in their careers (Schneidewind, 2009), the situation with them is only slightly better.

Amongst the problems hindering a further implementation of HESD are the various meanings of the term sustainability itself and its misinterpretations (Corcoran and Wals, 2004b). The concept is commonly understood in a far to narrow fashion, reducing sustainability to resource efficiency and more or less technical issues of environmental protection as well as economics and ESD to old-fashioned environmental education. Global social, cultural and ethical dimensions of sustainability as intra- and intergenerational balancing of interests are not commonly known. Therefore a large portion of academics do not relate to sustainability since they see it incorrectly as the sole domain for ecologists, engineers and economists. So instead of becoming a truly interdisciplinary field of study, it mostly remains in the realm of environmental sciences and engineering.

Another hidden reason for not teaching ESD at university level may be the general uneasiness of staff towards the complex task of teaching it properly. Despite a general demand for HESD, universities mostly do not invest in achieving sustainability literacy within their teaching staff. A recent study from Australia found numerous professional development programmes, but only 1 out of 38 universities offered its staff a course especially designed to introduce academics to the concept of sustainability and its teaching (Holdsworth et al., 2008). This is not exclusive for universities, since during the first 2 years of the UN-Decade for ESD, only 1,9\% of advanced training for school teacher's in the German federal state of Baden-Wuerttemberg focused on ESD (Riess and Mischo, 2007).

It may be an unrecognized part of the problem that universities can not be regarded as socially sustainable institutions themselves (Hammond and Churchman, 2008). On the contrary, recently universities have embraced their chance to stir away from indefinite towards temporary employment. In Germany over $30 \%$ of all academics younger than 30 years and even $40 \%$ of females in this class have only temporary contracts. As a consequence, today the university sector as a whole has the third respectively second highest rate of casualisation of its workforce in Germany and Australia, topped only by fruit pickers and unskilled workers (Grau, 2010; Junor, 2004). A recent study found temporary employment to be the single most demotivating factor for their working motivation under young academics in Germany (Gruehn et al., 2009). Thus it is not astonishing that those scientists finding themselves marginalised and employed under precarious and limited conditions do not wholeheartedly start teaching ESD.

It is quite illuminating to compare the current situation with the study titled "German Academia heading for sustainability?" by Adomssent and Michelsen (2006) written at the beginning of the decade for ESD. Clearly pointing out the importance of HESD in general, they made out several hindrances and several future hopes connected with the spreading of sustainability within German academia. But they already placed a question mark in their heading. They pointed out Germany's enormous responsibility for promoting HESD as one of the world's most powerful states. They identified as major hindrances that "higher education institutions are more or less independent institutions and as such they do have the freedom to 
decide whether or not to sign up to a policy idea such as sustainable development" and "the lack of an adequate framework for a consistent and concise German higher education policy that provides universities with financial and legal instruments to commit themselves to sustainable development". Further problems were associated with the powers of universities predominantly bound in struggle for becoming part of the governmental elite university scheme and sustainability issues being mostly due to individual commitment within the scientific community (Adomssent and Michelsen, 2006).

Hopes were associated, amongst others, with the Copernicus-University Charter adopted in 1993 by the European Rectors' Conference, the European Eco Audit scheme EMAS opening for public institutions as universities, an increasing variety of e-learning tools and ground breaking research on implementing sustainability in an university as a whole carried out at the university of Lueneburg. The latter even was meant as a template for other universities to follow the path to greater sustainability.

In this context it should be mentioned that universities as a whole very often exist much longer than the societies or states they operate in. This shows their overall extraordinary capacity to serve societies changing needs throughout time, in some cases for centuries, something to be said of only very few human institutions (Merkel and Litten, 2007). On the other hand, due to their complex structure, this overall flexibility is countered by a resistance to top-down change. It is harder than in other human institutions, e.g., enterprises, to implement institutional change via top-down mechanisms. Universities as a whole lack a clear corporate identity. With their constant fluctuation of members, their very diverse scholarly interests and the a priori limited time spent there by students, universities resemble rather a loose alliance of purpose of individuals through time. All these special properties tend to pose severe limits on their capacities to develop common institutional goals. It is well known that curriculum change in universities is generally a complex and demanding task with uncertain outcome, change towards the implementation of ESD in curricula being no exception (De La Harpe and Thomas, 2009).

Outlook: Now where do we stand at the beginning of 2010 in Germany? In an admittedly personal assessment, most actors within higher education institutions have not accepted sustainability as one of the major challenges of today, leaving it furthermore mostly to individual actors. This finding is supported by Desha and Hargroves (2010) survey of sustainability in engineering education in Australia where the ultimate driver for implementing ESD in courses is seen in the individual interests and research pursuits of the lecturers and not in a formal strategy of the institution to include HESD in it's training. Germany's higher education institutions are still lacking an adequate political and financial framework, even more so against the backdrop of the ongoing worldwide economic crisis and its more immediate demands. As they are still bound struggling to become elitist in nature, their institutional focus tends to shift even further away from sustainability (Schneidewind, 2009). The Copernicus-University Charter died a slow death forgotten by most of its signatories, but is currently reactivated as the Copernicus Alliance. The Eco Audit scheme EMAS was adopted by few universities in Germany, mostly universities of applied sciences and is far from becoming academic mainstream. In September 2010 only 9 out of more than 300 German universities and universities of applied sciences were certified, while several universities participating earlier already dropped out of EMAS again (for an up to date listing see www.emas.de). Interest in using the expertise from Lueneburg as a template to reach institutional sustainability is rather limited by other universities. All this led the speaker of the nationwide working group "University and Sustainability" associated with the official German Round Table for Sustainability to announce via email that "efforts have to be intensified to establish the issue of sustainability in the universities" (Mueller-Christ, pers. com. May 2009).

Even though this seems on the whole to be very disappointing there are also promising findings in our study. It is encouraging that only few people at university are real adversaries to HESD. Quite the contrary, at present there is an overall great awareness that sustainability matters. In March 2010 the German University Rectors' Conference (HRK) and the German Commission for UNESCO (DUK) published a joint strategic study titled 'Hochschulen für nachhaltige Entwicklung' ('Universities for Sustainable Development'). Hopefully, this publication of two of the highest ranking societal institutions in Germany will bring the issue of sustainability back to the top of the agenda. The majority of teaching staff agrees that sustainability issues should become mandatory in all degree programmes (see above); the approval for implementing HESD in all teacher training curricula is overwhelming. There is a real chance for sustainability to become a new key qualification. What is even more promising: Scientists across a great variety of disciplines are rising to the challenge of keeping this planet worth living on. When 
sustainability is now a common denominator ranging from the arts, cultural studies, social sciences and economics to natural sciences, there is a unique chance to start working truly interdisciplinary. And by leaving the ivory towers, engaging with stakeholders all over society, to tackle the most immediately threatening problems in a transdisciplinary way. Those familiar with researching and teaching sustainability should seek out their colleagues who at the moment are interested in HESD but have not found their way to get started with it. What is also very promising: Our students will be interested in HESD when we start teaching it. And when we accomplish the task to reveal its connectivity to nearly every discipline and nearly everybody within academia, interest should even be further on the rise in the near future.

\section{REFERENCES}

Adomssent, M. and G. Michelsen, 2006. German Academia heading for sustainability? Reflections on policy and practice in teaching, research and institutional innovations. Environ. Educ. Res., 12: 85-99. DOI: $10.1080 / 13504620500527758$

Adomssent, M., J. Godemann, A. Leicht and A. Busch, 2006. Higher Education for Sustainability: New Challenges from a Global Perspective. 4th Edn., Frankfurt/M.: VAS, ISBN: 978-3-88864-423-8, pp: 271.

BMBF, 2007. German Federal Ministry of Education and Research. Zur Entwicklung nationaler Bildungsstandards. Expertise. Bonn and Berlin. http://www.bmbf.bund.de/pub/zur_entwicklung_na tionaler_bildungsstandards.pdf

BMU, 2004. German Federal Ministry of the Environment. Umweltbewusstsein in Deutschland 2004, pp: 64. http://www.umweltdaten.de/publikationen/fpdf1/2792.pdf

BMU, 2008. German Federal Ministry of the Environment. Umweltbewusstsein in Deutschland 2008, pp: 64. http://www.umweltdaten.de/publikationen/fpdf1/3678.pdf

Corcoran, P. and A. Wals, 2004a. Higher Education and the Challenge of Sustainability. 1st Edn., Dordrecht: Kluwer, ISBN: 978-1-4020-2026-1, pp: 376.

Corcoran, P. and A. Wals, 2004b. The Problematics of Sustainability in Higher Education: An Introduction. In: Higher Education and the Challenge of Sustainability, Corcoran, P.B. and A. Wals (Eds.). Dordrecht, Kluwer, ISBN: 978-14020-2026-1, pp: 3-6.
Davidson, C.I., C.T. Hendrickson, H.S. Matthews, M. Bridges and D.T. Allen et al., 2010. Preparing future engineers for challenges of the $21 \mathrm{st}$ century: Sustainable engineering. J. Cleaner Product., 18: 698-701. DOI: 10.1016/j.jclepro.2009.12.021

De Haan, G., 2006. The BLK '21' programme in Germany: A 'Gestaltungskompetenz'-based model for education for Sustainable development. Environ. Educ. Res., 12: 19-32. DOI: 10.1080/1350462050052636

De Haan, G. and A. Leicht, 2009. Die Umsetzung der UN-Dekade "Bildung für nachhaltige Entwicklung" in Deutschland-eine Zwischenbilanz. Natur und Landschaft, 84: 103-107. http://www.natur-undlandschaft.de/kurzfassung/main03_09.htm

De La Harpe, B. and I. Thomas, 2009. Curriculum change in universities. Conditions that facilitate education for sustainable development. J. Educ. Sustainable Dev., 3: 75-85. DOI: 10.1177/097340820900300115

Desha, C., K. Hargroves and M.H. Smith, 2009. Addressing the time lag dilemma in curriculum renewal towards engineering education for sustainable development. Int. J. Sustain. Higher Educ., $\quad 10$ : $184-199 . \quad$ DOI: $10.1108 / 14676370910949356$

Desha, C. and K. Hargroves 2010. Surveying the state of higher education in energy efficiency, in Australian engineering curriculums. J. Cleaner Product. 18: 652-658.

Deutsche UNESCO Kommission e. V. und Hochschulrektorenkonferenz 2010. Hochschulen fur nachhaltige Entwicklung. http://www.hrk.de/de/download/dateien/Entschlies sung_Hochschulen_und_Nachhaltigkeit_HRK_DU K.pdf

Deutscher Bundestag, 2004. Beschlussempfehlung und Bericht des Ausschusses fuer Bildung, Forschung und Technikfolgenabschaetzung. (http://dip21.bundestag.de/dip21/btd/15/034/15034 72.pdf)

Grau, A., 2010. Befristete Beschaeftigung: Jeder elfte Vertrag hat ein Verfallsdatum. STATmagazin, Statistisches Bundesamt, Wiesbaden 2010 http://www.destatis.de/jetspeed/portal/cms/Sites/de statis/Internet/DE/Navigation/Publikationen/STAT magazin/2010/Arbeitsmarkt2010_032,templateId $=$ renderPrint.psml__nnn=true 
Gruehn, D., H. Hecht, J. Rubelt and B. Schmidt, 2009. Der wissenschaftliche, Mittelbau an deutschen Hochschulen. ver.di Vereinigte Dienstleistungsgewerkschaft, Berlin. http://www.tu-berlin.de/ fileadmin/f12/Downloads/koop/publikationen/End bericht_Verdi_Studie_09.pdf

Hammond, C. and D. Churchman, 2008. Sustaining academic life: A case for applying principles of social sustainability to the academic profession. Int. J. Sustain. Higher Educ., 9: 235-245. DOI: 10.1108/14676370810885862

Henke, R., 2010. Lower Saxony ministry of education, personal communication.

Holdsworth, S., C. Wyborn, S. Bekessyand I. Thomas, 2008. Professional development for education for sustainability. How advanced are Australian universities? Int. J. Sustain. Higher Educ., 9: 131-146. DOI: $10.1108 / 14676370810856288$

Holmberg, J. and B.E. Samuelsson, 2006. Drivers and barriers for implementing sustainable development in higher education. UNESCO Education for Sustainable Development in Action Technical Study N³.UNESCO Education Sector. http://unesdoc.unesco.org/images/0014/001484/14 8466e.pdf

Idros, S.S. and A.R. Mohamed, 2009. Greening the Teacher Education Program at University Sains Malaysia. In: Sustainability at UniversitiesOpportunities, Challenges and Trends, Filho, W.L. (Eds.). Frankfurt/M.: Peter Lang, pp: 95-108.

Junor, A., 2004. Casual university work: Choice, risk, inequity and the case for regulation. Econ. Labour Rela. Rev., 14: 276-304.

Kagawa, F., 2007. Dissonance in students' perceptions of sustainable development and sustainability. Int. J. Sustain. Higher Educ., 8: 317-338. DOI: $10.1108 / 14676370710817174$

Merkel, J. and L. Litten, 2007. The Sustainability Challenge. New Directions. Instit. Res., 134: 7-26. 10.1002/ir.209

Mula, I. and D. Tilbury, 2009. A United Nations Decade of Education for Sustainable Development (2005-14). What Difference will it Make? J. Educ. Sustain. Dev., 3: 87-97. DOI: 10.1177/097340820900300116
Mueller-Christ, G., 2009. University of Bremen, personal communication.

Niedersaechsisches Landesamt für Statistik, 2008. Hochschulstatistik $2006 . \quad$ Hanover. http://www.nls.niedersachsen.de/Download/Statisti scheBerichte/BIII1_4_2006.pdf

Riess, W. and C. Mischo (2007). Evaluationsbericht "Bildung für nachhaltige Entwicklung an weiterführenden Schulen in Baden-Württemberg". pp: 117. http://www2.uvm.baden-wuerttemberg.de/ servlet/is/43211/Evaluationsbericht_BNE_2007.pd f?command=downloadContent $\&$ filename $=$ Evaluati onsbericht_BNE_2007.pdf

Schneidewind, U., 2009. Nachhaltige Wissenschaft: Plaedoyer Fuer Einen Klimawandel im Deutschen Wissenschafts-Und Hochschulsystem. 1st Edn., Metropolis, Marburg, ISBN: 978-3-89518-745-2, pp: 290.

Schluchter, W. and C. Kunze, 2010. Umweltbewusstsein an der BTU Cottbus 2009, pp: 86. www.sozum.tu-cottbus.de/umweltbewusstsein 2009

Stir, J., 2006. Restructuring teacher education for sustainability: Student involvement through a strength model. J. Cleaner Product., 14: 830-836. DOI: 10.1016/j.jclepro.2005.11.051

UNESCO, 2009. Proceedings, UNESCO World Conference on Education for Sustainable Development, 31 March-2 April 2009 Bonn, Germany. http://www.esd-world-conference2009.org/fileadmin/download/ESD2009Proceeding sEnglishFINAL.pdf

Wright, T., 2004. The Evolution of Sustainability Declarations in Higher Education. Higher Education and the Challenge of Sustainability, Corcoran, P. and A. Wals (Eds.). Kluwer, Dordrecht, ISBN: 978-1-4020-2026-1, pp: 7-19. 